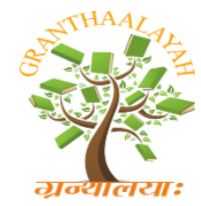

INTERNATIONAL JOURNAL OF RESEARCH GRANTHAALAYAH A knowledge Repository

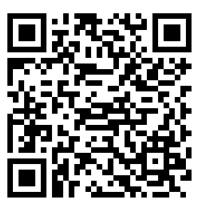

Management

\title{
IMPACT OF WORK LIFE BALANCE ON INSTITUTIONAL COMMITMENT AMONG MATHEMATICS WOMEN TEACHERS
}

\author{
D.Jeslin ${ }^{1}$, G.Ramesh Babu ${ }^{2}$ \\ ${ }^{1}$ Assistant Professor, Department of Mathematics, Sigma College of Architecture, Moododu, \\ Anducode-629168, Kanyakumari District, India \\ ${ }^{2}$ Assistant Professor, Department of Business Administration, Scott Christian College \\ (Autonomous), Nagercoil - 629 003, Kanyakumari District, India
}

DOI: https://doi.org/10.29121/granthaalayah.v4.i12SE.2016.2323

\begin{abstract}
Institutional commitment is the degree to which an employee identifies with a particular institution and wishes to maintain membership in the institution. An individual who has high institutional commitment is willing to exert extra effort on behalf of the institution, and has a strong desire to remain within the institution. The high level of institutional commitment reduces absenteeism and turnover. If an employee deeply committed to their institution perform roles beyond their formal job description. These extra roles improve institutional effectiveness. Those who are deeply committed to their institution give less time to their non-work life. Those who are strongly attached and committed to their institution tended to enjoy highly successful career and non-work life as well. The reason attributed to this is the job satisfaction such employees experience and relishes help them balance their career and home life. The objective of the study was to investigate the level of institutional commitment and the impact of work life balance on institutional commitment among the mathematics women school teachers in Kanyakumari district.
\end{abstract}

Keywords: Mathematics Women Teachers; Work Life Balance; Institutional Commitment.

Cite This Article: D.Jeslin, and G.Ramesh Babu. (2016). "IMPACT OF WORK LIFE BALANCE ON INSTITUTIONAL COMMITMENT AMONG MATHEMATICS WOMEN TEACHERS." International Journal of Research - Granthaalayah, 4(12)SE, 1-5. https://doi.org/10.29121/granthaalayah.v4.i12SE.2016.2323.

\section{Introduction}

Institutional commitment refers to an individual's affective reaction to the characters of the employing institution. Job characteristics, job rewards, availability of alternative job opportunities and personal characteristics of employee are the factors influencing institutional commitment. Teachers play integral roles in sustaining the health of their institutions through 
their contribution is teaching, service and research. In addition, their work is crucial to institutional reputations and excellence among the higher education community.

\section{Statement of the Problem}

Teachers' performance is critical for the success of educational institutions and the quality of services provided by teachers to their students. This poor performance may be attributed to lack of institutional commitment and low job satisfaction. The study sought to examine the relationship between institutional commitment and job satisfaction. Defined values, internal and external work factors, work life situation and satisfaction level, nature and type of institution, services over the years, number of teachers in a schools, changing attitude and perception of teachers, growth among the teachers role, stress, career development and forces from within and outside from academic sources. Hence an attempt is made to investigate the level of institutional commitment and the impact of work life balance on institutional commitment among the mathematics women school teachers in Kanyakumari district.

\section{Review of literature}

Cappelli (2014) is of the opinion that," institutions that seek to increase teacher morale, commitment and satisfaction, and reduce source of stress and problems at work, will improve their ability to recruit and retain talented and valued personnel"

Thomas and Ganster (2005) found that "teachers who used flexible practices had more control over managing work and family demands and had also higher job satisfaction".

\section{Methodology}

Proportionate stratified random sampling technique was used to select 127 respondents. The respondents were selected from government, government aided and unaided management schools in Kanyakumari district. Questionnaire was used to collect information from the respondents. Books, journal and magazines used as secondary sources.

\section{Objectives of the Study}

- To examine the level of institutional commitment

- To analyse the impact on institutional commitment and job satisfaction towards work life balance

\section{Analysis and Interpretation}

\section{Levels of Institutional Commitment}

Institutional commitment has positive effects on institutional performance. The level of institutional commitment among the teachers has been examined with the help of the mean scores of the statements related to institutional commitment. Regarding the institutional commitment, the significant differences among the three groups of respondent teachers have been analysed with the help of ' $F$ ' test. 
Table 1: Mean Score on Institutional Commitment among the Respondent Teachers

\begin{tabular}{|l|l|l|l|l|l|l|}
\hline \multirow{2}{*}{$\begin{array}{l}\text { Sl. } \\
\text { No. }\end{array}$} & \multirow{2}{*}{$\begin{array}{l}\text { Statements on Institutional } \\
\text { Commitment }\end{array}$} & \multicolumn{3}{|c|}{$\begin{array}{l}\text { Institution where the Teachers } \\
\text { Work }\end{array}$} & Overall & 'F' \\
\cline { 3 - 6 } & Government & Aided & Unaided & \\
\hline 1 & $\begin{array}{l}\text { I take the institution's issues } \\
\text { as my own issue }\end{array}$ & 3.42 & 3.32 & 3.03 & 3.26 & $10.11^{*}$ \\
\hline 2 & $\begin{array}{l}\text { I find that my values and the } \\
\text { institution's values are same. }\end{array}$ & 3.36 & 3.26 & 3.03 & 3.22 & $4.402^{*}$ \\
\hline 3 & $\begin{array}{l}\text { I am proud to tell others that I } \\
\text { am part of this institution }\end{array}$ & 3.67 & 3.6 & 3.04 & 3.45 & $24.14^{*}$ \\
\hline 4 & $\begin{array}{l}\text { I feel emotionally attached to } \\
\text { the institution }\end{array}$ & 3.83 & 3.46 & 3.12 & 3.46 & $26.11^{*}$ \\
\hline 5 & $\begin{array}{l}\text { I have a strong sense of } \\
\text { belonging for the institution }\end{array}$ & 3.64 & 3.7 & 3.14 & 3.51 & $17.15^{*}$ \\
\hline 6 & $\begin{array}{l}\text { I feel proud to work in the } \\
\text { institution }\end{array}$ & 3.84 & 3.78 & 3.09 & 3.59 & $42.38^{*}$ \\
\hline 7 & $\begin{array}{l}\text { My institution inspires my } \\
\text { work performance }\end{array}$ & 3.49 & 3.54 & 3.16 & 3.41 & $9.162^{*}$ \\
\hline
\end{tabular}

*Significant at five per cent level.

Table 1 explains the mean score of the variables on institutional commitment among the respondent teachers in government, management aided, unaided management school and its respective ' $F$ ' statistics. The highly rated institutional commitment variables among the respondent teachers in government school are 'I feel proud to work in the institution' and 'I feel emotionally attached to the institution' since their respective mean score are 3.84 and 3.83 respectively. The highly rated variables among the government aided school are 'I have a strong sense of belonging for the institution' and 'I feel proud to work in the institution' since their respective mean score are 3.78 and 3.7 respectively. The highly rated variables among the respondent teachers in unaided school are 'My institution inspires my work performance' and 'I have a strong sense of belonging for the institution' since their respective mean score are 3.16 and 3.14 respectively. The highly rated institutional commitments variable on overall level of the respondent teachers are 'I feel proud to work in the institution' and 'I have a strong sense of belonging for the institution' and since their respective mean score are 3.59 and 3.51. Regarding the institutional commitment on these variables, there is significant association among the three groups of respondent teachers have been noticed in the case of all six variables, since their respective ' $F$ ' statistics are significant at five per cent level.

\section{Impact of Work Life Balance on Institutional Commitment}

The work-life balance, in the present study, is analysed on the major factors of Work-Family Conflict and Family-Work Conflict. It is imperative to analyse the impact of the two measurers on the institutional commitment of the school teachers. The multiple regression analysis has been executed to analyse this impact. The fitted regression model is

$\mathrm{Y}=\mathrm{a}+\mathrm{b}_{1} \mathrm{x}_{1}+\mathrm{b}_{2} \mathrm{x}_{2}+\mathrm{e}$

Where

$\mathrm{Y} \quad$ - $\quad$ Score on institutional commitment among the respondent teachers 


$\begin{array}{lll}\mathrm{X}_{1} & - & \text { Score on WFC } \\ \mathrm{X}_{2} & - & \text { Score on FWC } \\ \mathrm{b}_{1}, \mathrm{~b}_{2} & - & \text { Regression coefficient of independent variables } \\ \mathrm{a} & - & \text { Intercept and } \\ \mathrm{e} & - & \text { Error term. }\end{array}$

The impact of work-life balance on institutional commitment has been measured among the respondent teachers from government, government aided and unaided schools and also for pooled data. The results are shown in Table 2.

Table 2: Impact of Work-Life balance on Institutional Commitment

\begin{tabular}{|l|l|l|l|l|l|}
\hline \multirow{2}{*}{ Sl. No. } & \multirow{2}{*}{ Factors } & \multicolumn{4}{|l|}{ Regression Co-efficient } \\
\cline { 3 - 6 } & & Government & Aided & Unaided & Pooled data \\
\hline 1. & WFC & $-0.253^{*}$ & $-0.376^{* *}$ & $-0.297^{* *}$ & $-0.251^{*}$ \\
\hline 2. & FWC & $-0.155^{*}$ & $-0.209^{*}$ & $-0.311^{* *}$ & $-0.282^{*}$ \\
\hline 3. & Constant & -2.145 & -2.378 & -3.158 & 2.973 \\
\hline 4. & $\mathrm{R}^{2}$ & 0.761 & 0.815 & 0.693 & 0.782 \\
\hline 5. & F - statistics & $137.52^{* *}$ & $140.38^{* *}$ & $167.35^{* *}$ & $149.58^{* *}$ \\
\hline
\end{tabular}

Source: Computed Data

**Significant at one percent level *Significant at five percent level

Table 2 reveals that the work family conflict and family work conflict have a significant negative impact on institutional commitment among the respondent teachers from government, aided and unaided category. The negative effects of work family conflict are higher in aided management school respondent teachers whereas the negative effects of family work conflict are higher in unaided management school respondent teachers, since their regression coefficient are -0.376 and -0.311. The analysis of pooled data reveals the significant impact of work family conflict and family work conflict. The changes on these work family conflict and family work conflict influence the institutional commitment since their regression coefficients -0.251 and-0.282 are significant at five percent level. The changes in work family conflict and family work conflict explain the changes in institutional commitment to the extent of 78.2 per cent since its $\mathrm{R}^{2}$ is 0.782 .

\section{Suggestions}

- Create awareness about the significance of work life balance

- Follow five working days in a week.

- Provide one or two days off with pay for approved community involvement work

- Take and utilize the vacation seriously 


\section{Conclusion}

The relative strength of an individual's identification and involvement in a particular institution is known as institutional commitment. Balancing home life and work enables you to meet several basic human needs. Poor work life balance create high stress, absenteeism and turnover. An institution one which may have the most employees - friendly policies in the form of vacation, teacher's assistance programme, various benefits and flexi work policies created higher institutional commitment

\section{References}

[1] Baterman, T.S. and Strasser, S. (1984), "A longitudinal analysis of the antecedents of organizational commitment”, Academy of Management Journal, 27(3): 95-112.

[2] Cappelli. (2014), "Understanding Employee Commitment in the public organizations: A study of the juvenile Detention centre", International Journal of Public Administration, 18(4): 126-129.

[3] Cook and Wall, T. (1980), "New work-attitude measures of Trust, Organizational commitment and personal need non-fulfillment", Journal of occupational psychology, 54(1): 39-52.

[4] Decotiis, T.A. and Summers, T.P. (1987), "A path analysis of a model of the antecedents and consequences of organizational commitment", Human relations, 40(4): 445-470.

[5] Golden, S. A. R. (2011). Strategy For Success Of Human Beings:- Time Management. Department Of BBA, St. Joseph's College, Trichy, 388, 390.

[6] Regi, S. B., \& Golden, S. A. R. (2014). A Study On Attitude Of Employee Towards Working Environment With Special Reference To RR Pvt Ltd. Review Of Research, 2 (2), 1, 5.

[7] Regi, S. B., Golden, S. A. R., \& Franco, C. E. (2014). Employee Perception Towards Effectiveness Of Hr Practices In Public Sector Banks In Tirunelveli District. Tactful Management Research Journal, 2 (6), 1, 4.

[8] Regi, S. B., Golden, S. A. R., \& Franco, C. E. (2014). Employee Perception Towards Effectiveness Of Hr Practices In Public Sector Banks In Tirunelveli District. Tactful Management Research Journal, 2 (6), 1, 4.

[9] Steers, R.M. (1997), "Antecedents and Outcomes of Organizational Commitments", Administrative Science Quarterly, 22(2): 46-56.

[10] Thomas and Ganster (2005), "Antecedents and Outcomes of Organizational Commitment", Administrative Science Quarterly, 22(2): 46-56.

\section{Authors Profile}

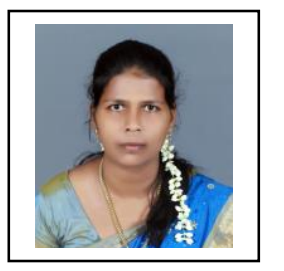

D.Jeslin working as Assistant Professor, Department of Mathematics,Sigma College of Architecture in Kanyakumari District from September 2012. She has completed M.Sc., B.Ed., M.Phil., . She has attended 16 national \& international seminars, conferences and workshops. She has presented 8 papers in national \& international seminars and conferences. She has published 5 papers in ISBN books.

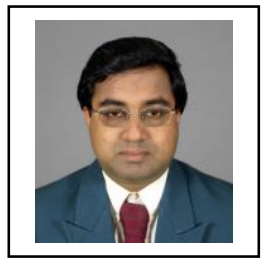

G.Ramesh Babu working as Assistant Professor, Department of Business Administration, Scott Christian College (Autonomous), Nagercoil since May 2005. He has completed M.B.A., M.Phil., M.L.M., M.A., M.Com., NET(Mgt.). He has attended 33 national \& international seminars, conferences, FDPs, workshops and refresher courses. He has presented 43 papers in national \& international seminars and conferences. He has published 18 papers in ISBN books and ISSN journals. He has served as board member, resource person, examiner, question paper setter in various Universities and Autonomous Colleges. 